\title{
Malignant extra-ovarian endometriosis: a case series of ten patients and review of the literature
}

Dr. Carolin POON*+ MBBS, B Med Sci, FRANZCOG ${ }^{1}$

Associate Professor Robert ROME* MBBS, FRCS (Ed), FRCOG, FRANZCOG, CGO

*Epworth Freemasons Victoria Parade. 320 Victoria Parade, East Melbourne, 3002.

+ The Royal Women's Hospital, 20 Flemington road, Parkville, Australia, 3052

\section{Correspondence}

Dr. Carolin Poon

Address:

Epworth Freemasons medical centre

Suite 115

320 Victoria Parade

East Melbourne, Victoria, Australia, 3002.

Fax number +61394188130

Telephone number: +61402831008

E mail address: carolin.poon@gmail.com

\footnotetext{
${ }^{1}$ Currently affiliated with The Mercy Hospital for Women, 163 Studley Road, Heidelberg, 3084. Working as a consultant obstetrician and gynaecologist.

This is the author manuscript accepted for publication and has undergone full peer review but has not been through the copyediting, typesetting, pagination and proofreading process, which may lead to differences between this version and the Version of Record. Please cite this article as doi: 10.1111/AJ0.13178
}

This article is protected by copyright. All rights reserved 
A/Prof Robert Rome

E mail address: rrome@bigpond.net.au

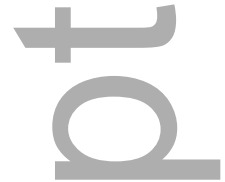

\section{Conflict of Interest Statement}

I declare that there are no conflicts of interest. This research has not received any financial support.

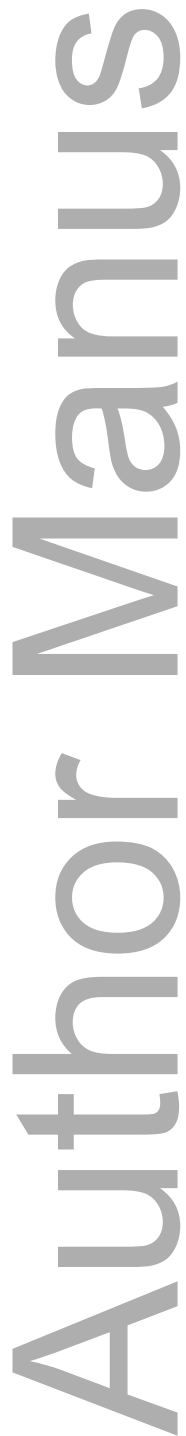

This article is protected by copyright. All rights reserved 
Malignant extra-ovarian endometriosis

Article type : Original Manuscript

6

7

8 Malignant extra-ovarian endometriosis: a case series of 9 ten patients and review of the literature

\section{Key Words}

12 Endometriosis; Malignant endometriosis; Endometriosis associated ovarian cancer; Endometriosis associated cancer; Malignant extra-ovarian endometriosis; Malignant transformation of endometriosis

Manuscript word count: 2598

Abstract word count: 245

Table count: 2

This article is protected by copyright. All rights reserved 
ABSRACT

30

\section{Background}

The malignant transformation of endometriosis within the ovary is a recognised condition. There is

less literature surrounding the malignant transformation of extra-ovarian endometriosis (MEOE).

Aims

We report our experience with MEOE in 10 patients and present a review of the literature regarding this rare malignancy.

\section{Materials and Methods}

For this retrospective case series, patients were identified from a practice-based database. Where required operative notes and pathology reports were reviewed.

Results

Ten patients diagnosed with MEOE between 1991 and 2014 were identified. In each case the tumour was localised to the pelvis and centred on the pouch of Douglas, broad ligament, obturator fossa, parametrium and rectovaginal septum. Tumour histology was endometrioid adenocarcinoma (6), clear cell carcinoma (2), and adenosarcoma (2). Five patients had a history of endometriosis and four had received oestrogen only hormone replacement therapy after hysterectomy and bilateral salpingo-oophorectomy.

50 Treatments included surgery (1), surgery and radiotherapy (1), surgery and chemotherapy (1), 51 surgery, radiotherapy and chemotherapy (3), and radiotherapy and chemotherapy (4). Maintenance

52 hormonal therapy was also used in 3 patients. Curative doses of radiotherapy $45 \mathrm{~Gy}$. Or more resulted in-field control in five patients. Six patients have no evidence of disease at a mean follow up 
54

57

60

61

62

63

64

65

66

67

68

69

70

71

72

73

77

78

67

\section{7}

period of 15 years (5.5-24 years). Severe G3 long-term bladder morbidity occurred in 3 patients after radical surgery and radiotherapy.

\section{Conclusion}

MEOE is a rare condition for which treatment needs to be individualised. Multicentrestudies and registries will hopefully define optimal treatment.
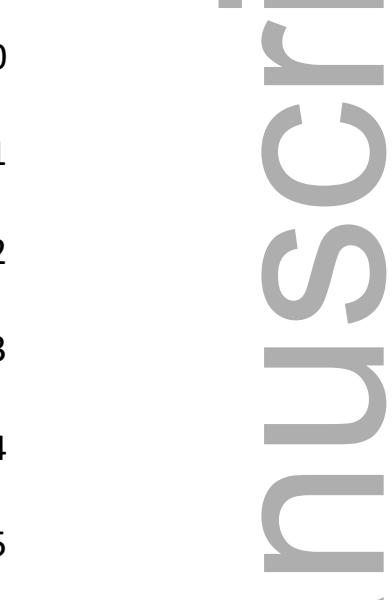

6
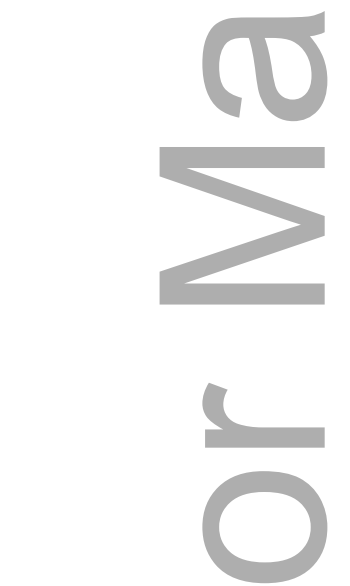

INTRODUCTION

Endometriosis is a common gynaecological condition characterised by the presence of endometrial glands and stroma outside the uterus. It is estimated to be present in $5-15 \%{ }^{1}$ of women in the reproductive age group, $25-80 \%$ of infertile women, $2-5 \%$ of postmenopausal women, and $40 \%-$ $80 \%$ of women with pelvic pain. ${ }^{2}$

Although endometriosis is considered to be a benign condition, this condition shares many pathological characteristics with malignant tumours, including tissue invasion and damage, neoangiogenesis and spread to distant sites $^{3}$. Furthermore, there are several epidemiological studies

This article is protected by copyright. All rights reserved 
that demonstrates that endometriosis is associated with an increased risk of various malignancies ${ }^{4,5}$. The incidence of malignant transformation ranges between $0.7-1 \%$ of patients with endometriosis ${ }^{6}$. Malignant transformation in the ovary accounts for about $80 \%$ of endometriosis associated malignancies ${ }^{7}$ with the remaining $20 \%$ occurring in extra-ovarian sites.

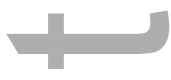

The malignant transformation of endometriosis within the ovary was first described by Sampson ${ }^{8}$ in 1925. He proposed that three criteria should be fulfilled for the diagnosis of malignant transformation within endometriosis to be made. These criteria included (1) demonstration of both cancerous and benign endometrial tissue in the tumour, (2) histology of the neoplasm is compatible with an endometrial origin, (3) no other primary tumour sites can be found. $\operatorname{Scott}^{9}$ later proposed a fourth criterion, namely demonstration of a dysplastic phase between the benign endometriosis and the carcinoma.

\section{Endometriosis-associated ovarian cancer (EAOC) is typically of endometrioid or clear cell type} histology. It is characterised by an early onset of disease, reported to occur on average 5.5 years earlier than those with non-endometriosis associated ovarian cancers. ${ }^{10}$ Furthermore, EAOC usually represents a low-stage, and low-grade disease, which is associated with a more favourable outcome. ${ }^{11}$ EAOC is staged and treated according to standard guidelines for ovarian cancer. ${ }^{12}$

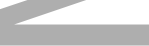

Women diagnosed with malignant extra-ovarian endometriosis (MEOE) are reported to be $10-20$ years younger than those with ovarian or endometrial cancer. ${ }^{13}$ The histopathology of MEOE is primarily represented by endometrioid carcinoma (69.1\%), sarcoma (25\%) and clear cell carcinoma (4.5\%). ${ }^{14}$ MEOE is a rare condition and there are very few case series in the literature ${ }^{15}$. Most recent papers appear as individual case reports describing MEOE in various sites, including abdominal wall scars mainly after caesarean section ${ }^{16}$, rectovaginal septum, pouch of douglas, uterosacral ligament, pelvicside wall, bladder ${ }^{17}$ and gastrointestinal ${ }^{18}$. MEOE is a rare condition and its management has not been not standardised. ${ }^{19}$

The purpose of this study is to report our experience with ten cases of MEOE, especially management and long-term outcomes and to review the literature on this ill-defined disease entity.

This article is protected by copyright. All rights reserved 
This study was approved by the Ethics Committee of Epworth HealthCare (EH 2017-211). The practice-based prospectively maintained database of a gynaecological oncologist was searched for all patients with a diagnosis of MEOE. We included patients that had an extra-ovarian malignancy amongst a background of benign endometriosis, and patients with an extra-ovarian malignancy of endometrial origin and a history of endometriosis, and/or a history of endometriosis for whom no other primary tumour site had been found.

120

Information was collected regarding the patient's age, parity, past medical history including history of endometriosis, family history, past or present use of hormone replacement therapy (HRT), operative findings, pathology results, further management and follow up. All patients gave informed consent for their treatment and had pathology review and presentation at a multi - disciplinary team meeting.

126

127

Radiotherapy (RT) intent was curative when the planned external beam dose was $45 \mathrm{~Gy}$. or more. Recurrence was defined as the diagnosis of cancer after a cancer-free interval. Progression was defined as worsening disease, when there was no cancer free interval after diagnosis. Recurrence and progression were measured from the date of diagnosis of MEOE. In- field control was defined as permanent control of tumour within the treated RT field. Complications were graded according to the RTOG/EORTC Late Radiation Morbidity Scoring Schema. ${ }^{20}$

A review of the literature was performed using Medline/Pubmed and Embase. This search was conducted by using the keywords "malignant endometriosis", "extra ovarian endometriosis" and "endometriosis associated cancer."

RESULTS

Ten patients with MEOE were identified. These cases were diagnosed during the years 1991 to 2014 . 
Table 1 summarises the patient and tumour characteristics. The mean age at diagnosis was 45.3 years (range 34 to 56). Six patients were nulliparous and five had undergone prior treatment for endometriosis. Four had undergone a hysterectomy and bilateral sal pingo-oophorectomy (TAH and BSO) for the management of endometriosis (cases 4, 7, 8 and 9) all four of whom had taken oestrogen only hormone replacement therapy (HRT) following their TAH and BSO. The interval from completion of TAH and BSO to MEOE was 4, 12, 3, 9 years respectively.

Pain was the most common presenting symptom, occurring in the pelvis, buttocks and hips. Severe neurological pain (from compression on the obturator nerve and sciatic nerve) occurred in cases 8 and 10. Patients also presented with altered bowel habit and abnormal uterine bleeding (AUB). The CA125 level was measured in 6 cases and it was elevated in five. In all 10 patients, the malignancy was confined to the pelvis at initial diagnosis and distant extra-pelvic spread was not detected. The most common location was the pouch of Douglas (POD), followed by the broad ligament and obturator foramen. Other locations include the parametrium and rectovaginal septum. Tumour size ranged from 6 to $13 \mathrm{~cm}$ (median $9 \mathrm{~cm}$ ).

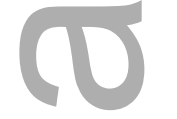

Table 2 summarises the pathology, management and outcomes. Six malignancies were endometrioid adenocarcinoma (two G1, one G2, and three G3), two were low-grade adenosarcoma, and two were high-grade clear cell.

\section{Treatment was individualised according to the location and size of their disease. Six patients} underwent surgery with the objective of complete removal of the tumour. There was no macroscopic residual tumour in one (case 1), macroscopic residual disease in four (cases 2, 5,7 and 9) and involved margins in one case (case 3 ).

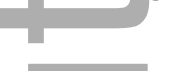

Initial management was surgical in six patients. After surgery, one patient received no further treatment (case 1) as they had an encapsulated tumour with negative surgical margins. Case 9 received post-operative chemotherapy and had a complete response lasting nine years. Four patients received postoperative external beam pelvic RT either al one (case 7) or combined with cisplatin based concurrent chemotherapy (case 3 and 5). In three cases the dose of RT ranged from 45-59 Gy. in 22-30 fractions, but in case 2 the RT was ceased before 45 Gy. because of acute toxicity. 
Initial management was non-surgical in four patients in whom the diagnosis had been made by core biopsy. Case 4 received neo-adjuvant chemotherapy (NACT) followed by RT after showing a partial response to Caelyx and case 6 showed a complete re sponse to chemo-RT. Response in each case was determined clinically and by PET/CT imaging. Two patients with advanced local disease (cases $8,10)$ received platinum-based chemotherapy and palliative RT but neither showed a definite response to this treatment. Case 10 also received hormonal treatment with medroxyprogesterone acetate (MPA dose 200mg bd but had progressive disease).

181

182

183

184

185

Six patients are NED 5.5-24 years after initial diagnosis (mean 15years). All four patients with grade 1 or low-grade tumours are NED compared with two of the six with grade 2, 3 or high-grade tumours. Four have remained free of recurrence. Their initial treatment had been surgery only (case 1), concurrent cis-platin chemo-RT (case 5, 6), and postoperative RT only (case 7). Both patients with low-grade adenosarcomas (cases 2,7) received long-term hormonal maintenance therapy with MPA (200mg BD). Case 7 also received Tamoxifen (20mg daily). They are NED after 23.5 and 24 years respectively.

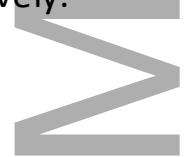

Two patients developed a late recurrence at the vaginal vault (case 2 ) and in a para-aortic lymph node (case 4) and both are currently NED 14 and 3 years after treatment of the recurrence. Two patients who developed late recurrence in the upper abdomen and liver (case 3) and POD (case 9) were treated with chemotherapy. Case 3 had a partial response lasting 6 months and case 9 had a further complete response lasting 9 months; however both subsequently died of their disease.

In-field control was achieved in the five (cases $3,4,5,6,7$ ) who received $45 \mathrm{~Gy}$. or more of RT of whom three (cases $3,5,6)$ had also received concurrent cis-platin based chemo-RT. Case 2 had not received a curative dose of RT and suffered a late in-field recurrence at the vaginal vault after 10 years. Infield control was not achieved in the two patients with extensive local disease (cases 8,10) who received palliative $\mathrm{RT}$ and chemotherapy. 
Three patients who had undergone complex/radical surgery followed by RT, experienced late radiation cystitis (G3). One patient has had multiple hospital admission for subacute small bowel obstruction (G3) probably due to adhesions and radiation enteritis but surgical intervention has not been required. One patient developed a disease-related colo-vesical fistula.

\section{DISCUSSION}
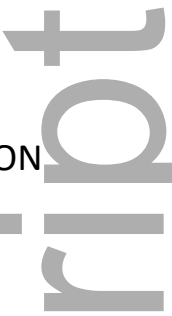

Whilst endometriosis is a common condition, endometriosis associated malignancies are relatively uncommon, and the ability of the clinician to predict which patients will go on to develop a malignancy within endometriosis and the management of these patients remains elusive. ${ }^{5}$ Nezhat et al. ${ }^{21}$ suggest that some characteristics of women with endometriosis that warrant ongoing follow -up includes women with a long-standing history of endometriosis, endometriosis-associated infertility or infertility treatment, or women with ovarian endometrioma. Our study supports this recommendation, as six of our patients had a long history of endometrios is with prior treatment, and six were nulliparous.

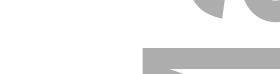

The management of patients with benign endometriosis may include observation, hormonal treatment or surgical excision. Nezhat et al. ${ }^{2}$ advocate complete surgical resection of all endometriotic foci in women undergoing surgical treatment, with tissue evaluation of ovarian endometriomas to rule out malignancy. The benefits of serial surgery to excise visible lesions needs to be balanced by the risks of major operative morbidity due to adhesions and other anatomical distortions. Furthermore, there is no definitive data that demonstrates early surgical treatment of limited implants is associated with a reduced risk of disease progression and malignancy. ${ }^{22}$ Nezhat et al. ${ }^{5}$ al so recommend ongoing hormonal treatment aimed at reducing the risk for recurrent endometriosis and endometriomas, as oral contraceptive use is associated with $80 \%$ lower occurrence of ovarian cancer in women with endometriosis who use the drug for more than 10 years, ${ }^{23}$ however it's efficacy in reducing malignant transformation in extra ovarian endometriosis is speculative.

\section{Caution should be taken when prescribing unopposed oestrogen hormone replacement therapy} (HRT) in women with a history of endometriosis as there has been an association noted between 
women with malignant endometriosis and unopposed oestrogen HRT, even in those women who have had a TAH BSO ${ }^{24}$. This risk factor was evident in our case series as four of six patients with known endometriosis had received unopposed oestrogen HRT.

\section{There are alimitednum}

There are a limited number of cases of MEOE in the literature, and its diagnosis is often based on circumstantial information. Most cases fulfil Sampsons ${ }^{8}$ three criteria for the diagnosis of malignant change in ovarian endometriosis. Only a minority of cases demonstrate a dysplastic transition from benign to malignant endometriosis as required by Scott's criteria ${ }^{9}$. The literature review by Benoit et al ${ }^{25}$ found that dysplastic transition is found in only $36-42 \%$ cases. This led Mostoufizadeh ${ }^{26}$ to regard that the co-existence of a neoplasm and endo metriotic tissue is sufficient to indicate an endometriotic origin. A history of endometriosis adds to the circumstantial evidence, especially when the malignancy has arisen in a site of known endometriosis. The issue is further confounded in patients who have received radiotherapy prior to surgical resection which can have a significant impact on tumour morphology as occurred in two cases ( 5 and 7 ) in which no residual malignancy was identified. We believe that it is time for Sampson's and Scott's criteria be expanded to include patients with a history of endometriosis.

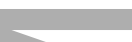

Due to the rarity of MEOE, therapeutic management has not been not standardised. ${ }^{19}$ Primary surgical treatment should be performed when feasible which aims to completely resect all disease and obtain staging biopsies of peritoneal surfaces and lymph nodes. ${ }^{25}$ Surgical resection may be challenging especially when the malignancy is located deep in the POD or rectovaginal septum and its infiltrative nature often results in residual disease after surgery. Ul rich et al. ${ }^{27}$ advocate radical surgery followed by radiation therapy as the treatment of choice.

Radiation therapy is effective in this condition and in-field control of disease was achieved in all 5 of our patients whose total dose of RT was $45 \mathrm{~Gy}$. or more. We recommend that RT should be used when the surgical resection is incomplete.

The role of chemotherapy is less clear. Published reports such as that by Heaps et al. ${ }^{15}$ suggest that that chemotherapy is ineffective in the treatment of ME, but most of their cases in their case-series and literature review predated the introduction of cisplatin. In a literature review conducted by Benoit et $\mathrm{al}^{25}$, they concluded that the effect of chemotherapy is minimal given its limited efficacy in 
endometrial cancer. In our series 5 patients with measurable disease received chemotherapy; there was one complete and two partial responses. Larger numbers are required before any conclusions about the effectiveness of chemotherapy can be drawn.

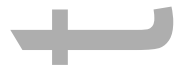

The place of chemo-radiotherapy is also not clear. It has been postulated that ME behaves more like endometrial carcinoma ${ }^{19,25}$. The recently publ ished PORTEC- $3^{28}$ phase 3 trial of women with high-risk endometrial cancer compared adjuvant chemotherapy during and after pelvic RT (chemoradiotherapy) versus pelvic RT alone. In that study chemo-radiotherapy did not improve 5year overall survival although it did increase failure-free survival. but it has some appeal in MEOE which is usually localised in the pelvis at the time of presentation. Two cases ( 5 and 6 ) in our series presented with large masses in the RVS and/or POD and both had prolonged complete responses to concurrent platinum based chemo-RT and are still alive with NED. Its role should be explored further as MEOE masses are usually large and localised in the pelvis at the time of presentation.

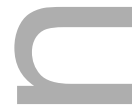

Heaps et al. ${ }^{15}$ recommended the use of progestin therapy in all cases of cancer arising in endometriosis. Hormone receptor testing to assess suitability for hormonal treatment was advocated by Brooks et al. and although this has theoretical appeal, there is currently no strong evidence that it is useful. In our study two patients with adenosarcomas received long-term maintenance progesterone treatment following initial treatment and are long-term disease-free survivors, but again there is no high-level evidence to support its use.

There is a fine balance between aggressive treatment of primary disease and recurrent disease versus the risk of major therapeutic morbidity..$^{30}$ In our series, four patients experienced serious complications to the bladder and/or bowel. These were often due to a combination of RT and surgery.

The prognosis formalignant transformation within MEOE confined to the genital tract, correlates well with stage. ${ }^{15}$ In the literature, patients with isolated disease of endometrioid histology, had an 82-100\% 5-year survival. However, disseminated intraperitoneal disease has a very poor associated prognosis, with a 0-12\% 5-year overall survival ${ }^{15,29}$ In our case-series none of our patients had tumour spread at the time of diagnosis and the five-year overall survival was $80 \%$. 
Malignant extra-ovarian endometriosis

296

297 The limitations of this study relate to small sample size, accrual of patients over a long period of time

298

299

300

301

302

303

304

305

306

307

308

309

310

311

312 and the individualisation and heterogeneity of treatments. Following these patients over a very long period has enabled us to report our long-term treatment outcomes. We cannot dogmatically define the optimal treatment of this rare disease and it would be very difficult for any one institution to accrue the necessary numbers. One way to progress would be to establish a multi-institutional registry of pathology, management and outcomes. More research needs to be done on this rare and challenging gynaecological malignancy.
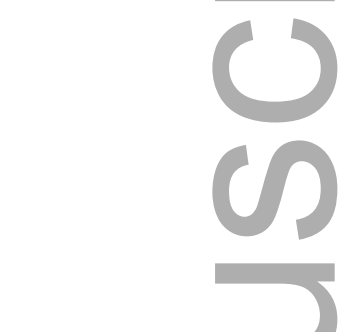

(1)

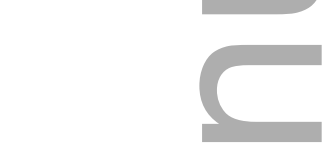

\section{REFERENCES}

[1] StencheverMA, Droegemueller W, Herbst AL, Mishell DR. Comprehensive gynecology. 4th ed. St. Louis: Mosby, 2001.

[2] Nezhat F, Datta MS, Hanson V, Pejovic T, Nezhat C, Nezhat C. The relationship of endometriosis and ovarian malignancy: a review. FertilSte ril 2008; 90:1559-70.

[3] Siufi NetoJ, Kho R M, Siufi D F. et al. Cellular, histologic, and molecular changes associated with endometriosis and ovarian cancer. J Minim Invasive Gynecol. 2014;21:55-63.

[4] Pearce CL, Templeman C, Rossing MA et al. Association between endometriosis and risk of histological subtypes of ovarian cancer: a pooled analysis of case -control studies. Lancet Oncol 2012; 13: $385-394$

[5] Nezhat FR, PejovicT, Reis FM, Guo SW. The link between endometriosis and ovarian cancer. Int J Gynecol Cancer 2014;24:623-8

[6] Chen Y, et al. Malignant transformation of residual endometriosis following hysterectomy and bilateral salpingo-oophorectomy in a female patient from a family with hereditary non-polyposis colorectal cancer. Oncology letters 5: 1253-1257, 2013. 
[7] Van Gorp T, Amant F, Neven P, Vergote I, Moerman P. Endometriosis and the development of malignant tumors of the pelvis. A review of the literature. Best Pract Res Clin Obstet Gynaecol. 2004;18:349-71.

[8] Sampson J. Endometrial Carcinoma of the ovary, arising in endometrial tissue in that organ. Arch Surg 1925; 10:1; 1-72

[9] Scott R. Malignant changes in endometriosis. Obstet Gynecol 1953;2:283-9.

[10] Aris A. Endometriosis-associated ovarian cancer: a ten-year cohort study of women living in the Estrie Region of Quebec, Canada. J Ovarian Res. 2010; 3:2.

[11] Krawcyzyk N et al. Endometriosis-associated malignancy. Geburtshilfe Frauenheilkd. 2016 Feb: 76(2): 176-181.

[12] First-line chemotherapy for the treatment of women with epithelial ovarian cancer:

Recommendations for the use of first-line chemotherapy for the treatment of women with epithelial ovarian cancer. A clinical practice guideline developed by cancer Australia. June 2014. ISBN Online: 978-1-74127-282-6

[13] Modesitt S, Tortolero-Luna G, Robinson J, Gershenson D, Wolf J. Ovarian and extraovarian endometriosis-associated cancer. Obstet Gynecol 2002;100:788-95.

[14] Matter M, Schneider N, McKee T. Cystadenocarcinoma of the abdominal wall following caesarean section: case report and review of the literature. Gynecol Oncol 2003;91:438-43.

[15] Heaps J, Nieberg R, Berek J. Malignant neoplasms arising in endometriosis. Obstet Gynecol $1990 ; 75: 1023-8$.

[16] Ferrandina G et al. Endometriosis-associated clear cell carcinoma arising in caesarean section scar: a case report and review of the literature. World Journal of Surgical Oncology (2016) 14:300

[17] Tarumi Y. Endometrioid adenocarcinoma arising from deep infiltrating endometriosis involving the bladder: A case report and review of the literature. Gynecologic Oncology Reports 13 (2015) 6870

[18] L Song et al. High-Grade serous carcinoma resulting from rectal endometriosis and complicated with ovarian cancer. Front Oncol. 2019 Nov 20;9: 1252

[19] Marchand E, et al. Malignant transformation of superficial peritoneal endometriosis lesion. BMJ Case Rep 2013007730 Aug 26 
[20] RTOG/EORTC late radiation morbidity scoring schema.

https://www.rtog.org/researchassociates/adverseeventreporting/rtogeortclateradiationmorbiditysc oringschema.aspx

[21] Nezhat F, Apostol R, Mahmoud M, Daouk M. Malignant transformation of endometriosis and its clinical significance. Fertility and Sterility. August 2014, Volume 102, Issue 2, Pages 342-344

358

359

360

361

362

363

364

365

366

367

368

369

370

371

372

373

374

375

376

377

[22] Vercellini P, Parazzini F, Somigliana E, Vigano P, Bolis G, Fedele L. The endometriosis -ovarian cancer connection: the case against preventive surgery. FertilSteril. 2009;91(5):e37.

[23] Modugno F, Ness RB, Allen GO, Schildkraut JM, Davis FG, Goodman MT. Oral contraceptive use, reproductive history, and risk of epithelial ovarian cancer in women with and without endometriosis. Am J Obstet Gynecol. 2004;191:733-740.

[24] Zanetta GM, Webb MJ, Hongzh L, Keeney GL. Hyperestrogenism: a relevant risk factor for the development of cancer from endometriosis. Gynecol Oncol 2000;79:18-22.

[25] Benoit L et al. Malignant extraovarian endometriosis: A review. EJSO32(2006)6-11.

[26] MostoufizadehM, Scully R. Malignant tumors arising in endometriosis. Clin Obstet Gynecol 1980;23:951-63.

[27] Ulrich U, et al. Parametrial and rectovaginal adenocarcinoma arising from endometriosis. Int J Gynecol Cancer 2005, 15, 1206-1209.

[28] De Boer SM, Powell ME, Mileshkin L, et al. Adjuvant chemoradiotherapy versus radiotherapy alone for women with high-risk endometrial cancer (PORTEC-3): final results of an international, open-label, multicentre, randomised, phase 3 trial. Lancet Oncol. 2018 Mar;19(3):295-309. Erratum in: Lancet Oncol. 2018 Apr;19(4):e184.

[29] Brooks J, Wheeler J. Malignancy arising in extragonadal endometriosis. Cancer 1977; 40:306573.

[30] Jaiman S et al. Malignant transformation of pelvic endometriosis: case series and review of the literature. Int J Surg Path. 2015; Vol 23 (6) 465-471.

This article is protected by copyright. All rights reserved 
Table 1. Clinical details of patients up to the time of diagnosis of malignant endometriosis.

\begin{tabular}{|c|c|c|c|c|c|c|c|}
\hline Pt & Age & $\begin{array}{l}\text { History of endometriosis (and treatment) } \\
\text { and other gynaecological history }\end{array}$ & Past Medical History & HRT & Parity & $\begin{array}{l}\text { Symptoms, signs and CA125 } \\
\text { level at diagnosis }\end{array}$ & $\begin{array}{l}\text { Location of } \\
\text { malignancy }\end{array}$ \\
\hline 1 & 42 & & None rel evant & $\mathrm{Nil}$ & $\mathrm{P} 2$ & $\begin{array}{l}\text { Abdominal bloating and mass. } \\
\text { CA125 not done }\end{array}$ & Right pelvis; $9.5 \mathrm{~cm}$. \\
\hline 2 & 50 & No & None rel evant & $\mathrm{Nil}$ & P3 & Pelvic pain. Ca 125 not done. & POD \\
\hline 3 & 48 & No & $\begin{array}{l}\text { Later developed } \\
\text { breast DCIS aged } 62 \\
\text { years }\end{array}$ & $\mathrm{Nil}$ & P0 & $\begin{array}{l}\text { Vaginal bleeding and discharge; } \\
\text { ulcer in L vaginal fornix; CA125 } \\
\text { not done. }\end{array}$ & $\begin{array}{l}\text { POD and } \\
\text { parametrium; } 6 \mathrm{~cm} .\end{array}$ \\
\hline 4 & 56 & $\begin{array}{l}\text { TAH/BSO aged } 52 \text { years for benign } \\
\text { endometriosis in L. ovary, residual } \\
\text { endometriosis in POD. } \\
\text { Removal of benign endometrioma in POD, } \\
\text { anterior resection and loop ileostomy aged } \\
53 \text { years. Treated with Zoladex x } 6 \text { months. }\end{array}$ & None rel evant & $\begin{array}{l}\text { Oestrogen only } \\
\text { for } 1.1 \text { years }\end{array}$ & PO & $\begin{array}{l}\text { LIF pain and L sacro-iliac pain. } \\
\text { CA125 } 57 \mathrm{u} / \mathrm{ml} \text {. }\end{array}$ & $\begin{array}{l}\text { POD; mostly cystic; } \\
\text { fluid cytology } \\
\text { positive; } 13 \mathrm{~cm} .\end{array}$ \\
\hline 5 & 54 & $\begin{array}{l}\text { TAH/BSO aged } 42 \text { years for fibroids and } \\
\text { adenomyosis. Endometriosis was not noted. }\end{array}$ & None rel evant & $\begin{array}{l}\text { Oestrogen only } \\
\text { for } 9 \text { years. }\end{array}$ & P4 & $\begin{array}{l}\text { Pelvic pain. } \\
\text { CA125 84u/ml. }\end{array}$ & RV septum; $6 \mathrm{~cm}$. \\
\hline 6 & 41 & No & Infertility & $\mathrm{Nil}$ & P0 & $\begin{array}{l}\text { Constipation and pelvic pain } \\
\text { CA125 } 243 \mathrm{u} / \mathrm{ml} \text {. }\end{array}$ & $\begin{array}{l}\text { POD and RV } \\
\text { septum; } 9 \mathrm{~cm} .\end{array}$ \\
\hline 7 & 34 & $\begin{array}{l}\text { Long history of endometriosis and infertility. } \\
\text { TAH/BSO aged } 31 \text { years for severe } \\
\text { endometriosis }\end{array}$ & None rel evant & $\begin{array}{l}\text { Oestrogen only } \\
\text { for } 3 \text { years }\end{array}$ & PO & Pelvic pain & POD; 8cm. \\
\hline
\end{tabular}

This article is protected by copyright. All rights reserved 


\begin{tabular}{|c|c|c|c|c|c|c|c|}
\hline 8 & 35 & $\begin{array}{l}\text { Laparotomy, exploration of right obturator } \\
\text { fossa, drainage of endometrioma excision of } \\
\text { endometriosis right USL aged } 29 \text { years. } \\
\text { Treated with Zoladex x } 6 \text { months. Then } \\
\text { progestogen. }\end{array}$ & None relevant & $\mathrm{Nil}$ & PO & $\begin{array}{l}\text { Pain R hip. } \\
\text { CA125 19u/ml. }\end{array}$ & $\begin{array}{l}\mathrm{R} \text { broad ligament, } \\
\text { obturator foramen, } \\
\text { bony pelvis; }>10 \mathrm{~cm} .\end{array}$ \\
\hline 9 & 49 & $\begin{array}{l}\text { Hormonal treatment from age } 26 \text { years with } \\
\text { progestogen. RSO for endometrioma aged } \\
30 \text { years. LSO aged } 35 \text { years. TAH aged } 40 \\
\text { years. }\end{array}$ & $\begin{array}{l}\text { Breast DCIS aged } 46 \\
\text { years. Myel oma aged } \\
49 \text { years. }\end{array}$ & $\begin{array}{l}\text { Oestrogen only } \\
11 \text { years. }\end{array}$ & PO & $\begin{array}{l}\text { Pelvic pain } \\
\text { CA125 42u/ml. }\end{array}$ & POD; $6 \mathrm{~cm}$. \\
\hline 10 & 44 & $\begin{array}{l}\text { CT guided drainage of endometriosis from } \\
\text { obturator internus aged } 39 \text { years. }\end{array}$ & None relevant & $\mathrm{Nil}$ & P2 & $\begin{array}{l}\text { Pain L buttock } \\
\text { CA125 548u/ml. }\end{array}$ & $\begin{array}{l}\text { L hemipelvis, } \\
\text { obturator foramen, } \\
\text { bony pelvis; partly } \\
\text { cystic; } 13 \mathrm{~cm} \text {. }\end{array}$ \\
\hline
\end{tabular}

\section{Abbreviations}

POD - Pouch of Douglas; USL - utero sacral ligament; LIF

TAH - total abdominal hysterectomy

BSO - Bilateral salpingo-oohporectomy

LSO/RSO - L and R salpingo-oophorectomy

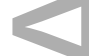

$\mathrm{RV}=$ rectovaginal $\mathrm{RV}$ septum

This article is protected by copyright. All rights reserved 
Table 2. Pathology, treatment and outcomes after the diagnosis of malignant endometriosis.

\begin{tabular}{|c|c|c|c|c|c|c|c|}
\hline No. & Pathology & $\begin{array}{c}\text { Primary debulking } \\
\text { surgery }\end{array}$ & $\begin{array}{l}\text { Radiation } \\
\text { therapy }\end{array}$ & $\begin{array}{c}\text { Chemothera } \\
\text { py }\end{array}$ & $\begin{array}{l}\text { Hormonal } \\
\text { treatment }\end{array}$ & Recurrence/clinical course & Outcome \\
\hline 1 & $\begin{array}{l}\text { Endometrioid ca; } \\
\text { G1 }\end{array}$ & $\begin{array}{l}\text { Debulking pelvic mass, } \\
\text { no residue. Ovaries } \\
\text { normal, not removed. }\end{array}$ & None & None & None & No further problems & $\begin{array}{l}\text { Patient well with NED } \\
\text { at } 10.4 \text { years. }\end{array}$ \\
\hline 2 & $\begin{array}{l}\text { Adenosarcoma; } \\
\text { low-grade }\end{array}$ & $\begin{array}{l}\text { TAH/BSO. Ovaries } \\
\text { normal. Residual tumour } \\
\text { in POD. }\end{array}$ & $\begin{array}{l}\text { Pelvic EBRT } \\
\text { (incomplete due } \\
\text { to acute toxicity), } \\
\text { vault BT }\end{array}$ & $\begin{array}{l}\text { Cisplatin, } \\
\text { doxorubicin, } \\
\text { ifosfamide } \\
\text { after RT }\end{array}$ & MPA & $\begin{array}{l}\text { Recurred after } 10 \text { years at vaginal vault. } \\
\text { Upper vaginectomy, further EBRT. } \\
\text { Complications: radiation cystitis, non- } \\
\text { functioning bladder managed by ISC. G3. }\end{array}$ & $\begin{array}{l}\text { Patient well with NED } \\
\text { at } 24 \text { years. }\end{array}$ \\
\hline 3 & Endometrioid ca; & $\begin{array}{l}\text { RHBSO and upper } \\
\text { vaginectomy. Involved } \\
\text { margins. }\end{array}$ & $\begin{array}{l}\text { Pelvic EBRT, } \\
\text { Cisplatin chemo- } \\
\text { RT }\end{array}$ & $\begin{array}{l}\text { Carboplatin, } \\
\text { paclitaxel } \\
\text { after RT }\end{array}$ & None & $\begin{array}{l}\text { Recurred after } 14.3 \text { years in left upper } \\
\text { quadrant of abdomen and liver. Treated } \\
\text { with MPA; progressive disease over } 3 \\
\text { months. Then carboplatin, paclitaxel with } \\
\text { only partial response for } 6 \text { months and then } \\
\text { carboplatin, caelyx with no response. }\end{array}$ & $\begin{array}{l}\text { Died from progressive } \\
\text { disease at } 16.1 \text { years. }\end{array}$ \\
\hline 4 & Clear cell ca & Not done & $\begin{array}{l}\text { Pelvic EBRT } \\
\text { (after NACT) }\end{array}$ & $\begin{array}{l}\text { NACT prior } \\
\text { to RT with } \\
\text { Carboplatin, } \\
\text { paclitaxel } \\
\text { then partial } \\
\text { response to } \\
\text { caelyx }\end{array}$ & None & $\begin{array}{l}\text { Recurred at } 8.5 \text { years in para-aortic LN. } \\
\text { Para-aortic LN debulking. Carboplatin and } \\
\text { paclitaxel chemotherapy then EBRT to PA } \\
\text { region. }\end{array}$ & $\begin{array}{l}\text { Patient well with NED } \\
\text { after } 11.5 \text { years. }\end{array}$ \\
\hline
\end{tabular}

This article is protected by copyright. All rights reserved 


\begin{tabular}{|c|c|c|c|c|c|c|c|}
\hline 5. & Endometrioid ca; & $\begin{array}{l}\text { Vaginal evacuation of } \\
\text { rectovaginal tumour. }\end{array}$ & $\begin{array}{l}\text { Pelvic EBRT, } \\
\text { (concurrent } \\
\text { cisplatin) }\end{array}$ & None & None & $\begin{array}{l}\text { PET scan after } 4 \text { months showed possible } \\
\text { persistent disease in the RVS. Vaginectomy, } \\
\text { anterior resection, loop ileostomy and } \\
\text { Martius flap. Residual benign endometriosis } \\
\text { but no cancer. } \\
\text { Complications: radiation cystitis, recurrent } \\
\text { UTIs. G3. }\end{array}$ & $\begin{array}{l}\text { Patient well with NED } \\
\text { at } 15.0 \text { years. }\end{array}$ \\
\hline 6 & $\begin{array}{l}\text { Endometrioid ca; } \\
\text { G3 }\end{array}$ & Not done & $\begin{array}{l}\text { Pelvic EBRT, } \\
\text { (concurrent } \\
\text { cisplatin) }\end{array}$ & $\begin{array}{l}\text { Gemcitabine } \\
\text { after RT. } \\
\text { Complete } \\
\text { response to } \\
\text { chemo-RT }\end{array}$ & None & No further problems. & $\begin{array}{l}\text { Patient well with NED } \\
\text { at } 5.5 \text { years. }\end{array}$ \\
\hline 7 & $\begin{array}{l}\text { Adenosarcoma; } \\
\text { low-grade }\end{array}$ & $\begin{array}{l}\text { Debulking pelvic masses } \\
\text { and femoro-femoral } \\
\text { artery bypass graft. }\end{array}$ & Pelvic EBRT & None & $\begin{array}{l}\text { Tamoxifen, } \\
\text { MPA }\end{array}$ & $\begin{array}{l}\text { Laparotomy and drainage of collection with } \\
\text { colostomy after } 11 \text { months, no cancer, only } \\
\text { fibrosis. } \\
\text { Complications: RT cystitis with urinary } \\
\text { incontinence requiring ISC. Recurrent SBO. } \\
\text { Surgery not required. G3. }\end{array}$ & $\begin{array}{l}\text { Patient well with NED } \\
\text { at } 23.5 \text { years. }\end{array}$ \\
\hline 8 & Endometrioid; & Not done & $\begin{array}{l}\text { Palliative EBRT to } \\
\text { R hemi-pelvis and } \\
\text { buttock }\end{array}$ & $\begin{array}{l}\text { NACT with } \\
\text { Carboplatin, } \\
\text { paclitaxel } \\
\text { prior to RT }\end{array}$ & None & $\begin{array}{l}\text { Progressive disease in } \mathrm{R} \text { hemipelvis and } \\
\text { bony pelvis. }\end{array}$ & $\begin{array}{l}\text { Died of progressive } \\
\text { disease at } 10 \text { months. }\end{array}$ \\
\hline
\end{tabular}

This article is protected by copyright. All rights reserved 


\begin{tabular}{|c|c|c|c|c|c|c|c|}
\hline 9 & Clear cell ca & Debulking tumour mass & None & $\begin{array}{l}\text { Carboplatin, } \\
\text { paclitaxel } \\
\text { after initial } \\
\text { surgery. } \\
\text { Complete } \\
\text { response. }\end{array}$ & None & $\begin{array}{l}\text { Recurred at } 6.0 \text { years with pelvic mass. } \\
\text { Retreated with carboplatin, paclitaxel; } \\
\text { interval debulking. } \\
\text { Complications: paraneoplastic occipital } \\
\text { infarct after } 1 \text { cycle of chemotherapy. } \\
\text { Disease-related colovesical fistula; G4 }\end{array}$ & $\begin{array}{l}\text { Died of progressive } \\
\text { disease at } 8.2 \text { years }\end{array}$ \\
\hline 10 & $\begin{array}{l}\text { Endometrioid } \\
\text { adenocarcinoma; } \\
\text { G2 }\end{array}$ & Not done & $\begin{array}{l}\text { Palliative EBRT to } \\
\text { L hemipelvis and } \\
\text { buttock }\end{array}$ & $\begin{array}{l}\text { Carboplatin, } \\
\text { paclitaxel } \\
\text { before, } \\
\text { during and } \\
\text { after RT }\end{array}$ & MPA & $\begin{array}{l}\text { Progressive disease in pelvis, bony pelvis, } \\
\text { retro-peritoneal LNs and lungs. }\end{array}$ & $\begin{array}{l}\text { Died of progressive } \\
\text { disease at } 24 \text { months. }\end{array}$ \\
\hline
\end{tabular}

\section{Abbreviations:}

NED = no evidence of disease

$\mathrm{NACT}=$ neo-adjuvant chemotherapy

ISC = intermittent self-catheterisation;

$\mathrm{LN}=$ lymph node;

RVS = rectovaginal septum;

POD = cul-de-sac;

MPA = medroxyprogesterone acetate, usual dose $200 \mathrm{mg} \mathrm{bd}$

This article is protected by copyright. All rights reserved 
$\mathrm{BT}=$ brachytherapy; EBRT = external beam RT

$\mathrm{TAH}=$ total abdominal hysterectomy; $\mathrm{BSO}=$ bilateral salpingo-oophorectomy

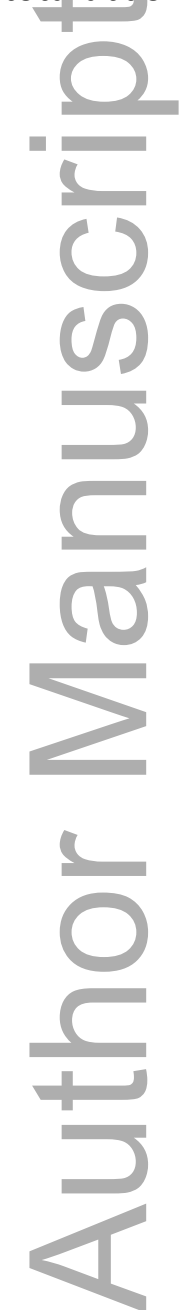

This article is protected by copyright. All rights reserved 


\section{University Library}

\section{- M M N E R VA A gateway to Melbourne's research publications}

Minerva Access is the Institutional Repository of The University of Melbourne

Author/s:

Poon, C;Rome, R

Title:

Malignant extra-ovarian endometriosis: A case series of ten patients and review of the literature.

\section{Date:}

2020-08

\section{Citation:}

Poon, C. \& Rome, R. (2020). Malignant extra-ovarian endometriosis: A case series of ten patients and review of the literature.. Aust N Z J Obstet Gynaecol, 60 (4), pp.585-591. https://doi.org/10.1111/ajo.13178.

Persistent Link:

http://hdl.handle.net/11343/275783 